\title{
Infrastructure and economic growth in Peru
}

\author{
Roberto Urrunaga and Carlos Aparicio
}

ABSTRACT

This article reviews the literature analysing the importance of infrastructure for economic growth, and performs an econometric estimation to discover the relation between the two variables in the case of Peru. Different estimators are used with panel data from the 24 regions of Peru for the period 1980-2009. The econometric results confirm that public-service infrastructures (roads, electricity and telecommunications) are important in explaining temporary differences in regional output, in keeping with neoclassical exogenous growth theories. Evidence is also found of significant differences in the repercussions of the different infrastructures on per capita gdp in each region. Consequently, the policy authorities should streamline the development of projects that help to reduce the infrastructure disparities that hinder the development of Peru's regions.

KEYWORDS

JEL CLASSIFICATION

AUTHORS
Physical infrastructure, roads, electric energy, telecommunications, economic growth, regional development, gross domestic product, econometric models, Peru

C33, H54, L90, O11, O18, O40, R11

Roberto Urrunaga is professor and lead researcher at the Department of Economics and at the Universidad del Pacifico Research Centre (Lima, Peru).urrunaga_rl@up.edu.pe

Carlos Aparicio is an analyst at the Economic Research Department of the Superintendency of Banks, Insurance and Private Pension Funds of Peru and professor at the Department of Economics of Universidad del Pacifico (Lima, Peru). caparicio@sbs.gob.pe 


\section{I}

\section{Introduction}

As a fundamental input for private-sector activities, infrastructure is directly related to production and stimulates economic growth. Studies that summarize the main findings on this relation include Straub (2008a); González, Guasch and Serebrisky (2007), and Cárdenas, Gaviria and Meléndez (2005).

The key mechanism through which infrastructure affects output and economic growth involves raising the productivity of capital, and this effect will be more pronounced the greater the complementarity between infrastructure and the productive investment made by firms. According to Straub (2008a), other mechanisms include infrastructure maintenance activities, which increase along with the infrastructure itself; adjustment costs, which decrease as a result of the lower logistics costs generated by the new investments; higher labour productivity, resulting from workers with better information and communication technologies (ICT's) and better health and education conditions; and lower transport costs, owing to the exploitation of economies of scale and scope.

Studying the relation between infrastructure and productive growth is particularly interesting in the

$\square$ The authors are grateful to Carlos Cubas and Regina Ruiz for their help in producing this paper, and to an anonymous referee from cepal Review for comments made on a preliminary version. Any error or omission is the authors' exclusive responsibility.
Peruvian case, given the vigorous growth of its economy and major progress in terms of developing public service infrastructures. In this context, the main hypothesis of this article is that this infrastructure has a major repercussion on output and economic growth in Peru's regions. The article also considers whether there are significant differences in the contribution of infrastructure to the productive development of the regions of Peru. To this end, panel data are used containing information for Peru's 24 regions over the period 1980-2009, under different econometric estimators. Given the existing information shortcomings, the article works with data on road, telecommunication and electricity energy infrastructures.

The importance of undertaking this type of study stems from the fact that Peru and many other Latin American countries still face infrastructure problems that can limit their growth opportunities, so it is necessary to raise awareness among the authorities at the different government levels to speed up the pace of concession processes and public infrastructure investments.

This article is structured as follows. Following the introduction, section II reviews literature dealing with the relation between infrastructure and economic growth. Section III then discusses the relevant methodological issues. Section IV analyses the results obtained from the estimated models, and section $\mathrm{V}$ sets forth conclusions and recommendations.

\section{II}

\section{Literature review}

\section{Theoretical framework}

Table 1 summarizes the main studies that have addressed the relation between economic growth and infrastructure. There is consensus in viewing public infrastructure investment as an important component of economic growth. This was initially verified in practice by Aschauer (1989) and later corroborated by authors such as Easterly and Rebelo (1993); Canning (1999) and Calderón and
Servén (2004b), and also by Vásquez and Bendezú (2008) for the case of Peru. Nonetheless, the discussion does not seem to focus on the direction of the effect, but on its magnitude. Thus, for example, the literature review performed by Straub (2008a), found a negative effect in just $6.5 \%$ of the studies, all of which used an inappropriate infrastructure indicator (as will be shown below); in contrast, $37.5 \%$ of the studies obtained neutral results, whereas $55.8 \%$ of them produced positive coefficients. 
The pioneering work of Aschauer (1989) is one of the main studies to have found empirical evidence of the positive effect of infrastructure on output. This author argues that the fall in the productivity of capital in the United States in the 1970s and 1980s reflected a reduction in public investment in infrastructure. In particular, the author identifies transport (roads, ports and airports), energy and sanitation infrastructures as those having greatest effects on productivity.

The first step in embarking on a discussion of the literature at the theoretical level is to propose a production function that explicitly includes the variables of interest - the public infrastructure stock - as done in Straub (2008a):

$$
Y=A(\theta, F) . F(K, L, I(N))
$$

where $Y$ is aggregate output, $A$ is the productivity term, $K$ is the capital stock (excluding infrastructure), $L$ is labour, and $I(N)$ is a variable representing intermediate inputs in which public infrastructure $(N)$ is the key variable. The level of infrastructure is separated from $K$, where it is usually included, such that $I(N)$ reflects the direct effect of $N$. By including infrastructure as an explanatory factor of $A$ (the indirect effect of $N$ ), it is assumed that infrastructure has an effect on total factor productivity. All other factors that might affect the productivity term are encompassed by the variable $\theta$.

Theoretically, it is preferable to model the direct effect of infrastructure through the services it provides $I(N)$, instead of including it in the production function directly. Firstly, as indicated by Romp and de Haan (2007), including the infrastructure variable directly would mean assuming that it has pure public good characteristics and provides services proportionate to the quantity of infrastructure, without rivalry or exclusion in consumption. In practice, public infrastructure does not produce anything itself; it simply provides services (such as transport and communications) which are incorporated within enterprise cost functions (Hulten, Bennathan and Srinivasan, 2006).

Secondly, Pritchett (1996) explains that infrastructure investments are generally not determined through market mechanisms, but tend to be influenced by the regulatory framework, which generally faces imperfect information problems (Laffont and Tirole, 1993). They are also generally susceptible to political interference (Guasch, Laffont and Straub, 2005), because in many cases they involve natural monopolies. This means that firms cannot take decisions on the cost of the quantity of infrastructure they use (Duggal, Saltzman and Klein, 1999; Hulten, Bennathan and Srinivasan, 2006).
Moreover, the indirect effect of infrastructure means assuming that its accumulation generates externalities that raise the general efficiency of the economy. Prud'homme (2005) argues that infrastructure has a similar effect to that of lowering tariffs, because it makesit possible to increase the size of the market, leading to greater specialization, more intensive competition, economies of scale, and a larger effective labour market. Duggal, Saltzman and Klein (1999) add that infrastructure also has an important network effect. An example of this is the quality of electricity supply, which makes it possible to use more sophisticated machinery (Hulten, Bennathan and Srinivasan, 2006).

Public infrastructure also differs from general capital in other ways. Firstly, infrastructure tends to come in large units, and fractions of it cannot provide any service; accordingly, an infrastructure work needs to be completed to be useful. In most cases this will imply large-scale investments and long waiting periods to receive services from the infrastructure in question.

In some cases, the relation between public infrastructure and the level and variation of output may be ambiguous, because certain infrastructure works are developed exclusively to improve the well-being of a given population group, prioritizing redistribution ahead of economic efficiency. Moreover, according to Barro and Sala-i-Martin (1990) and Glomm and Ravikumar (1994), infrastructure may become congested, so its repercussion on the economy will depend on the level of congestion at a given point in time. Nonetheless, if the increase in the infrastructure stock occurs when existing infrastructure is not congested, it will not generate major benefits, since it will not significantly improve the quality of the service. This could mean that in some cases it is better to invest in maintaining existing infrastructure rather than building a new one (Hulten, 1996).

The productivity of infrastructure investments will largely depend on other bottlenecks in the economy such as institutional quality (particularly contractual mechanisms), the level of competition (state enterprises, concessions, public-private partnerships, and others) and the project approval mechanism.

Another key point of discussion concerns the duration of the effects of new infrastructures, in other words whether the effects would be permanent or temporary. According to Straub (2008b), the former means assuming that the infrastructure generates sufficient externalities to induce constant returns to scale in aggregate terms, as in the endogenous growth case. Secondly, assuming the effects to be temporary means that any infrastructure investment will have a decreasing returns, for which 
the neoclassical case of exogenous growth would be applicable, where public infrastructure affects output, but not the long-term growth rate.

According to Mankiw, Romer and Weil (1992), the empirical evidence shows that output variations are adequately explained by maintaining the assumption of decreasing returns to scale of capital. Accordingly, the possibility of analysing output differences based on a Solow model should not be ruled out (Solow, 1956).

Lastly, from a public-policy standpoint, it is interesting to discuss the possibility that an optimal point exists for the infrastructure stock, which could be found easily by equalling its marginal cost to its social benefits. Nonetheless, calculating the cost of infrastructure is a major challenge.

\section{Techniques used}

Although the theoretical relation between investment in different types of public infrastructure and the growth of gross domestic product (GDP) has been very clearly explained in numerous studies of the topic, difficulties arise when trying to express this theoretical relation in an econometric model. This is due mainly to three issues: (i) how to deal with the endogeneity that exists between infrastructure investment and economic growth; (ii) what infrastructure measure reflects its true effect on aggregate output, and then how to separate the effect of each type of infrastructure on output; and, lastly, (iii) what additional controls are needed to avoid confusing the effect of infrastructure with that of other variables linked to the country's economic and political environment.

Table 1 shows the results of the main studies reviewed in terms of the contribution made by infrastructure to economic growth. The earliest studies estimated a simple linear regression, based on a monetary indicator of infrastructure expenditure; and many authors believe this approach explains why both Aschauer (1989) and Munnell (1990) obtain such large elasticities for infrastructure. Later studies, such as Devarajan, Swaroop and Zou (1996) and García-Milà, McGuire and Porter (1996), obtain lower or even negative results, using a panel-data model with fixed effects that capture the unobserved differences between countries. Nonetheless, Canning (1999), Calderón and Servén (2004b) and Straub, Vellutini and Warlters (2008) obtain larger coefficients for infrastructure investment measured by a physical indicator. Other studies, such as those of Rivera and Toledo (2004) and Vásquez and Bendezú (2008), find a cointegration relation between the infrastructure variables and economic growth, using the Johansen method; and these authors later attempt to find the short-term relation in an error-correction model (see table 1).

\section{The endogeneity of the model}

With regard to the first issue, most of the studies mention three main sources of endogeneity: the presence of unobserved fixed effects in models applied to many countries or regions; the existence of dual causality between output and infrastructure investment; and multiple problems related to omitted variables in the model and measurement error in the infrastructure variables.

Both Aschauer (1989), which uses regional information from United States, and Munnell (1990), which prepares a panel of various countries, find very high values for the elasticity output with respect to infrastructure $(0.31$ in the first case and 0.54 in the second). Gramlich (1994) points out that these results are not consistent with reality, since elasticities like those would imply a marginal return of $100 \%$; in other words, the infrastructure would fully cover their costs in one year.

Later studies such as Holtz-Eakin (1994) and García-Milà, McGuire and Porter (1996), claim that these high results reflect the omission of a fixed effect that captures unobserved effects between the countries or regions analysed. These studies report considerably lower results than the first-generation studies. Straub (2008b) reviews 51 studies that apply panel data -25 of which include fixed effects - and finds on average that infrastructure has smaller effect on output in studies that applied fixed effects.

The second possible manifestation of endogeneity in these models is the presence of dual causality between the infrastructure investment variables and output, which could give an upward bias to the results, even where a fixed effect is explicitly included. The ideal is to be able to apply a test that indicates the direction of the causality unambiguously. Unfortunately, in most cases, this test cannot be done owing to the nature of the data, so an alternative solution needs to be found.

A first alternative is that adopted by Canning and Pedroni (2004), using panel data. These authors find that the long-term relation and short-term correction between infrastructure and output varies across countries. As they find that both variables are non-stationary but co-integrated, they can estimate an error-correction model without including a priori restrictions. Then, by introducing restrictions into the model, the direction of the causality can be determined. 
TABLE 1

Summary of the main studies

\begin{tabular}{|c|c|c|c|c|c|}
\hline Study & Evaluated countries & Sample & Infrastructure variable & Methodology & Elasticity \\
\hline Aschauer (1989) & United States & 1949-1985 & $\begin{array}{l}\text { Public expenditure on } \\
\text { non-military capital }\end{array}$ & OLS & 0.39 \\
\hline Munnell (1990) & United States & 1947-1988 & $\begin{array}{l}\text { Public expenditure on } \\
\text { infrastructure }\end{array}$ & OLS & 0.34 \\
\hline Canning (1999) & 57 developing countries & 1960-1990 & Telecommunications & Fixed effects panel & 0.139 \\
\hline $\begin{array}{l}\text { Easterly and Rebelo } \\
\text { (1993) }\end{array}$ & 28 developing countries & 1970-1988 & $\begin{array}{l}\text { Expenditure on transport } \\
\text { and telecommunications }\end{array}$ & OLS & 0.16 \\
\hline $\begin{array}{l}\text { Esfahani and } \\
\text { Ramírez (2003) }\end{array}$ & 75 countries & 1965-1995 & $\begin{array}{l}\text { Telecommunications } \\
\text { and energy }\end{array}$ & 2-stage OLS & $\begin{array}{l}0.091 \text { and } \\
0.156\end{array}$ \\
\hline $\begin{array}{l}\text { Vásquez and Bendezú } \\
\text { (2008) }\end{array}$ & Peru & 1940-2003 & Roads & Cointegration & 0.218 \\
\hline $\begin{array}{l}\text { Rivera and Toledo } \\
(2004)\end{array}$ & Chile & $1975-2000$ & $\begin{array}{l}\text { Sector investment } \\
\text { in infrastructure }\end{array}$ & Cointegration & 0.16 \\
\hline \multirow{2}{*}{$\begin{array}{l}\text { Sánchez-Robles } \\
\text { (1998) }\end{array}$} & 57 countries & 1970-1985 & Infrastructure index & OLS & 0.009 \\
\hline & 19 Latin American countries & & & & 0.012 \\
\hline $\begin{array}{l}\text { Devarajan, Swaroop } \\
\text { and Zou (1996) }\end{array}$ & 43 developing countries & $1970-1990$ & $\begin{array}{l}\text { Expenditure on transport } \\
\text { and telecommunications }\end{array}$ & Fixed effects panel & -0.025 \\
\hline \multirow{2}{*}{$\begin{array}{l}\text { Calderón and Servén } \\
(2004 b)\end{array}$} & 101 countries & $1960-2000$ & Infrastructure index & Fixed effects panel & 0.0195 \\
\hline & & & & GMM & 0.0207 \\
\hline \multirow[t]{2}{*}{$\begin{array}{l}\text { Straub, Vellutini and } \\
\text { Warlters (2008) }\end{array}$} & 92 emerging countries & 1971-1995 & $\begin{array}{l}\text { Telecommunications, } \\
\text { roads and energy }\end{array}$ & Fixed effects panel & $0.028 ; 0.029$ and 0.018 \\
\hline & 40 low-income countries & & & & $0.03 ;-0.043$ and 0.028 \\
\hline $\begin{array}{l}\text { Duggal, Saltzman } \\
\text { and Klein (1999) }\end{array}$ & United States & 1960-1989 & $\begin{array}{l}\text { Public expenditure on } \\
\text { roads and structures }\end{array}$ & $\begin{array}{l}\text { OLS, non-linear } \\
\text { specification }\end{array}$ & 0.27 \\
\hline $\begin{array}{l}\text { García-Milà, } \\
\text { McGuire and Porter } \\
\text { (1996) }\end{array}$ & United States (48 states) & 1971-1983 & $\begin{array}{l}\text { Public expenditure on } \\
\text { water, drainage, and } \\
\text { express highways }\end{array}$ & Fixed effects panel & $\begin{array}{l}-0.058 \text { and } \\
-0.029\end{array}$ \\
\hline
\end{tabular}

Source: Prepared by the authors.

OLs: Ordinary least squares.

GMM: Generalized method of moments.

Rivera and Toledo (2004) and Vásquez and Bendezú (2008) follow this route in an attempt to identify the existence of a cointegration relation between the infrastructure variables $(N)$ and output $(Y)$. For this purpose, they firstly have to perform unit root tests to effectively rule out the presence of a trend component or structural break in the series. In both cases it was found that the variable had a unit root.
Another possible approach is to solve a simultaneous equations system that includes an equation explaining GDP and another that explains infrastructure. In this case, the problem would consist in identifying the functional form of the second equation, since the components that generate infrastructure investment may vary across countries.

Some authors have opted to solve endogeneity by taking the first differences of the components, to be 
able to analyse the feedback effect of output growth on infrastructure investment, as done by González, Guasch and Serebrisky (2007) and Esfahani and Ramírez (2003). In the case of panel data, this differentiation also helps to eliminate the unobserved component corresponding to each of the $n$ countries analysed. Nonetheless, this approach does not make it possible to test the longterm relation that exists between the two variables of interest, and ignores the possibility that the series may be cointegrated.

Aschauer (1989) and Calderón and Servén (2004b) use internal instruments such as lags in the explanatory variables of interest. This is preferable to the previous alternative, because it explicitly estimates the autoregressive process of the series. This produces robust coefficients: most research using this methodology obtained similar coefficients for infrastructure investment with respect to other types of capital investment; and their results are also consistent with the internal rates of return reported in many World Bank transport and telecommunications projects, as noted by Bandyopadhyay and Devarajan (1993). These models are estimated in parallel using ordinary least squares (oLs) and the generalized method of moments (GMM).

Sánchez-Robles (1998) and Alesina and Perotti (1993) apply a similar procedure using infrastructure variables measured at the start of the period and output variables measured at the end of the period. The solution represents a concept similar to internal instrumentalization, except that the choice of that instrumentalization is preferable since it imposes fewer a priori conditions on the instruments to be used.

In contrast, García-Milà, McGuire and Porter (1996) find that, in this type of research, using a squared panel makes it possible to save on the internal instrumentalization step. This observation is corroborated by Straub (2008b), who shows that in the case of panel data studies instrumentalization with lagged values of the explanatory variables themselves does not change the results of the model.

\section{Choice of infrastructure indicator and separation of effects}

All of the studies reviewed included one of two types of infrastructure indicator: a monetary measure of the investment in public infrastructure, or a physical index of infrastructure related to the services it provides.

Indicators of the first type are normally used to measure investment in public capital. Nonetheless, this method does not necessarily encompass investments in public infrastructure exclusively because it can also capture investments in State buildings and Stateowned machinery. Another failing in the first type of indicator is that the private sector share in the provision of this type of infrastructure is increasingly important (telecommunications is a clear example in Peru), so the public-capital measure would be insufficient. Moreover, measuring the amount invested by private firms in public infrastructure could be difficult, because firms generally try to keep their cost structures as confidential as possible. Lastly, the investment cost is often not related to the quantity of infrastructure that is actually built.

The choice of a physical infrastructure seems a better alternative, but it is not problem- free. The empirical evidence conclusively shows that levels of investment in the different types of public infrastructure are highly correlated. This poses a dilemma: including each type of public infrastructure separately invalidates the oLS estimator by reducing its efficiency owing to the presence of multicollinearity; but summarizing the information in a single indicator makes it impossible to identify which type of public investment is the most productive.

In practice, most authors -including Calderón and Servén (2004b) and Sánchez-Robles (1998) — have decided to attempt both approaches, by estimating in parallel one equation that includes an aggregate index of infrastructure and others that include one type of public infrastructure at a time. The differences in the coefficients of the different types of public infrastructure indicate which of them is most productive. In both cases, the indices are prepared using variables from three sectors: transport (length of the road network within the country's total territory), electricity generation (electricity generating capacity in per capita terms) and telecommunications (number of telephone lines per capita); so an increase in any of these variables will raise the value of the index.

In the case of the infrastructure index, most authors follow Alesina and Perotti (1993), who designed an index of sociopolitical instability based on the principal components method. This method aims to summarize the information contributed by a set of highly correlated variables in a single variable (first principal component) that best explains the variance of all of the series together. For that purpose, it is important that all variables have the same direction, ${ }^{1}$ to ensure a valid interpretation of the principal component. In this case, an increase in the value of the principal component implies an increase in

\footnotetext{
1 The scale of measurement and magnitude would not be that important because the variables can easily be normalized.
} 
general political instability (the specific manifestation of the political instability is irrelevant here).

Limao and Venables (2001) use a public-infrastructure index in a model that attempts to explain transport costs. To construct the index they use the following variables: kilometres of road, kilometres of paved road, kilometres of railway line (all three divided by the area of the country) and the number of telephone lines per person. The authors argue that the four variables listed are highly correlated, and it is impossible to identify the effect of each one on transport costs. They opt to use the linear average of the standardized infrastructure variables, which means assuming that the different types of public infrastructure are perfect substitutes for each other for a given transport service function. The authors decide not to use the principal components method, because the data emerging from the research is incomplete for many of the types of infrastructure analysed in different countries.

The study by Calderón and Servén (2004b) uses information from Latin America, so it is the only study in which an infrastructure index has been constructed for the Peruvian case in this context. It is also worth noting that none of the studies reviewed performed a regional analysis within a given country, except for Vásquez and Bendezú (2008), precisely for Peru.

Before discussing which additional variables are needed to avoid overestimating the effect of infrastructure owing to the omission of other relevant variables, there is the need todecide how to separate the direct and indirect effects of infrastructure on growth. There is not much literature that attempts to address this point directly. Most studies use a Cobb-Douglas function that does not make it possible to explain indirect effects in general. Growth accounting methods also are unable to distinguish such effects, because - as discussed above - it is not easy to attribute a price to infrastructure capital. As infrastructure is partially a public good, its contribution to output cannot be estimated on a partial basis.

Of the studies reviewed, the only one that models the contribution of infrastructure through its indirect effect is Duggal, Saltzman and Klein (1999). These authors use a non-linear model and include an infrastructure index as an additional factor of the Solow residual. They find a positive infrastructure effect with a similar magnitude to that found by Aschauer (1989), and that this effect has a positive feedback with technological progress.

\section{Choice of control variables}

The final point in the methodological discussion concerns the role played by control variables for the correct specification of the model. There are two types of variables that make it possible to correct potential specification problems: dummy variables, which capture the presence of structural breaks, and variables related to the business cycle. This is necessary because often the effect of the parameters varies through time, or else they follow a given cycle. This is particularly relevant for regional or cross-sectional studies.

On the first point, Rivera and Toledo (2004) and Vásquez and Bendezú (2008) perform studies to detect the presence of a structural break in the cases of Chile and Peru, respectively. This reflects changes in the type of management of the entities responsible for undertaking public infrastructure investment in those countries, which occurred in the early 1990s.

Vásquez and Bendezú (2008) also include the fiscal cycle and the export cycle as additional control variables, which were calculated using the HodrickPrescott filter, to eliminate the trend of the fiscal and export series, respectively, to explain short-term GDP fluctuations correctly.

This procedure is also consistent with Canning (1999), which included a dummy variables series to control for the phase of the business cycle in which the economy was situated. Nonetheless, one should not confuse the variable used by Canning (1999) with the dummy variable used by Rivera and Toledo (2004) and Vásquez and Bendezú (2008) to correct for structural breaks. The variable used by Canning (1999) aims merely to reflect the phase of the business cycle, which is related to the fiscal and export cycle variables used by Vásquez and Bendezú (2008). Lastly, the dummy variables used by Rivera and Toledo (2004) and by Vásquez and Bendezú (2008) relate to changes in the type of management of public infrastructure works. 


\section{III}

\section{Methodological considerations}

\section{Models and estimation methods}

The starting point is equation (1) shown in the previous section, which is used to break down the capital stock into three components: non-infrastructure physical capital (C), human capital $(\mathrm{H})$ and public-service infrastructure $I(N)$. The new expression is thus:

$$
Y_{i t}=A_{i t} \cdot H_{i t}^{\beta} \cdot C_{i t}^{\alpha} \cdot I(N)_{i t}^{\gamma} \cdot L_{i t}^{1-\alpha-\beta-\gamma} \cdot U_{i t}
$$

where the subscripts $\alpha, \beta, \gamma$ and " $1-\alpha-\beta-\gamma$ " reflect the individual factor shares in the production function: physical capital, human capital, public service infrastructure and labour, respectively. If the sum of the shares is 1 , the production function has constant returns to scale; if it is less than 1 , there are decreasing returns to scale, and if it totals more than 1 , there are increasing returns.

Similarly, the subscripts $i$ and $t$ correspond to individual $i$ (each Peruvian region) in time $t$. Lastly, $U_{i t}$ is the error term.

Taking logarithms of both sides of equation (2), gives the following expression (which is interpreted in per capita terms):

$$
y_{i t}=a_{i}+b_{t}+\beta h_{i t}+\alpha c_{i t}+\gamma I(n)_{i t}+u_{i t}
$$

where the first two terms of the equation correspond to total factor productivity $(A)$, as indicated by Canning (1999):

$$
A_{i t}=\alpha_{i}+b_{t}
$$

Thus, $A_{i t}$ comprises $\alpha_{i}$, which is the constant factor and specific for each region (unobservable heterogeneity), and $b_{t}$, which is productivity growth, common to all regions in period $t$.

Estimating panel data with fixed effects would allow each region to have its own level of total factor productivity without the need to calculate it. In fact, attempting to include productive improvement explicitly could generate measurement errors when estimating through the Solow (1956) residual in the conventional way.
Nonetheless, it is necessary to include $h_{i t}$, which is the human capital indicator; $c_{i t}$, the non-infrastructure physical capital stock, and $n_{i t}$, which represents public service infrastructure. As this article aims to estimate the effect of three types of public-service infrastructure on per capita output, the term $n_{i t}$ (which stems from the assumed $I(n)$ function) can be broken down into the following components:

$$
n_{i t}=e_{i t}+t_{i t}+r_{i t}
$$

where $e_{i t}, t_{i t}$ and $r_{i t}$ are indicators reflecting electricity, telecommunications, and road infrastructure respectively, for each region at each point in time. It was decided to use these infrastructures only, owing to information shortcomings for the other infrastructures both regionally and in terms of their characteristics. Firstly, there is no information on access to water and sanitation in a long series at the regional level. Secondly, the heavy centralization of port and airport activity in the country's capital means that the other regions have little port and airport activity, and it is insignificant in explaining regional output. Railroad infrastructure is also not very important in productive terms compared to roads and highways in the regions of Peru. Lastly, the weak penetration of broadband infrastructure and scant access to natural gas (these infrastructures have been developing for less than 10 years in Peru, and natural gas is only supplied in the capital) mean that they are not yet relevant in explaining differences in output at the regional level.

It should be noted that in this specification the $I(n)$ function is assumed linear. This implies that there are no complementarities between the different types of infrastructure, which is not necessarily true for some infrastructures, such as telecommunications, that require the presence of electric energy to operate. Nonetheless, the linear relation is assumed since the aim is to analyse the contribution of each type of infrastructure to regional productive growth; and estimating another type of function could distort the results, since part of the repercussion of each infrastructure on output would be absorbed by other infrastructure.

Equation (3) is then transformed into expression (6), which is what this study estimates: 


$$
y_{i t}=A_{i t}+\beta h_{i t}+\alpha c_{i t}+\delta e_{i t}+\lambda t_{i t}+\sigma r_{i t}+u_{i t}
$$

To capture potential differentiated repercussions of the different infrastructures on per capita output in the regions, dummy variables were constructed for each region, and interactions between these variables and the infrastructure variables in the model are added.

This model is interesting because it shows the temporary effect of infrastructure on economic activity. According to Straub (2008b) and Mankiw, Romer and Weil (1992), this type of model reflects neoclassical exogenous growth theory, where infrastructure affects output but not the long-term growth rate.

This specification uses the oLs estimator and the instrumental variables (IV) estimator through the GMM method, assuming a pooled model (estimated through the IV-GMM estimator). These estimators do not consider endogeneity between the variables and the unobservable heterogeneity that exists between regions; but it is worth including them to evaluate the robustness of the econometric results obtained. In addition, this model is estimated through the oLs estimator for a static panel data model, which does incorporate unobservable heterogeneity. In contrast, it is not estimated from the within-group estimator (of fixed effects), since this eliminates the model's unobservable heterogeneity. It is important to control for unobservable heterogeneity under this specification, because it captures the repercussions of productivity on output. For that reason, it is assumed that unobservable heterogeneity is not correlated with the explanatory variables.

To undertake a more complete analysis, models in differences were also estimated to identify the effect of the different infrastructures on regional economic growth. ${ }^{2}$

$$
\begin{gathered}
\Delta y_{i t}=\Delta A_{i t}+\zeta \Delta h_{i t}+\eta \Delta c_{i t}+ \\
\psi \Delta e_{i t}+\omega \Delta t_{i t}+\phi \Delta r_{i t}+\Delta u_{i t}
\end{gathered}
$$

This model is estimated through oLs, IV-GMM, generalized least squares (GLS) (random effects) and the within-group estimator (fixed effects). The latter is justified because the model is estimated in difference form; accordingly, a model is estimated that does not consider the specific unobservable component of each

\footnotetext{
2 As the variables are expressed in logarithms, estimating the model in differences means that the dependent variable becomes the growth of per capita regional output and the estimated coefficients would be
} the elasticities. region, related to productivity. Moreover, estimating the model in differences eliminates potential unit roots related to the variables used in the specification.

It is important to note that by eliminating the productivity component in this specification, the main explanation for economic growth under the neoclassical exogenous growth models is lost. Thus, this model would be indirectly evaluating whether the long-term productive growth of the regions is endogenous ${ }^{3}$ and whether infrastructure has a significant effect.

Dynamic panel models are also estimated with the lagged dependent variable as explanatory variable, estimated through both difference and system GMM:

$$
\begin{gathered}
\Delta y_{i t}=\alpha \Delta y_{i t-1}+A \Delta_{i t}+\zeta \Delta h_{i t}+\eta \Delta c_{i t}+ \\
\psi \Delta e_{i t}+\omega \Delta t_{i t}+\phi \Delta r_{i t}+\Delta u_{i t}
\end{gathered}
$$

The GMM in difference form applied to dynamic panel models makes it possible to control for potential endogeneity in the explanatory variables - since it instrumentalizes the variables based on the first and second lags of the variables used in the estimation - and to take account of potential persistence of the dependent variable (Arellano and Bond, 1991; Arellano and Bover, 1995; Blundell and Bond, 1998). This is important for evaluating an endogenous growth model.

Under this estimator, different sets of conditions are assumed for moments involving different levels and differences of the explanatory variables as additional instruments. This follows the recommendations made by Ashauer (1989) and Calderón and Servén (2004b) to use an internal instrumental variable process to estimate the relation between infrastructure and economic growth. The estimator under GMM is as follows:

$$
\delta_{m g m}=\left(\Delta X^{\prime} Z W_{N} Z^{\prime} \Delta X\right)^{-1} \Delta X^{\prime} Z W_{N} Z^{\prime} \Delta Y
$$

In this expression, $Z$ is the matrix of instruments, $X$ is the matrix of explanatory variables, $Y$ is the dependent variable of the model, and $W_{N}$ is the positivedefined weights matrix $\left[\frac{1}{N} \sum_{i=1}^{N}\left(Z_{i}^{\prime} \Delta \hat{v}_{i} \Delta \hat{v}_{i}^{\prime} Z_{i}\right)\right]^{-1}$. This latter expression includes the $\Delta \hat{v}_{i}$, which are the estimates consisting of the first in differences of the residuals obtained from a prior consistent estimator. Accordingly, $\delta_{m g m}$ is a two-stage estimator.

\footnotetext{
3 Testing this hypothesis more effectively requires a change in the model's specification to eliminate the presence of decreasing returns to scale of factors of production.
} 
According to Blundell and Bond (1998), the GMM model in first differences is biased and inaccurate in finite samples when the lagged variables of the series are weakly correlated with the subsequent first differences, so that the instruments for the equations in first difference form are weak. Accordingly, these authors impose additional restrictions on the model to obtain a larger number of moment conditions. Exploiting the additional moment conditions in some cases can generate a significant increase in efficiency and reduction of selection bias (Blundell and Bond, 1998). It is therefore also useful to estimate the model through the system GMM, which includes a larger number of instruments.

To evaluate the validity of the instruments based on the use of the GMM estimator (in difference and system form) the Sargan test is used — contrasting the specification used to test the validity of restrictions that over-identify the instrumental variables. The null hypothesis of this test is the lack of correlation between the instruments and the residuals in the first differences model.

Lastly, a serial-correlation test should also be performed(Arellano and Bond, 1991). Under the null hypothesis of the absence of serial correlation between the errors of the estimation, a significant negative correlation should be found in the residuals of the equation in first difference form and no second-order correlation in these residuals. The dynamic-panel specification used will only be valid if both conditions are simultaneously fulfilled.

\section{Data and variables}

The study considered data from the 24 regions of Peru in the period 1980-2009. Official information sources were used: National Institute of Statistics and Informatics (INEI), the Supervisory Agency for Private Investment in Telecommunications (OSIPTEL), the Ministry of Energy and Mines (MINEM) and the Ministry of Transport and Communications (MTC), although in some cases, the authors own assumptions and estimations were included to complete the data series.

According to the model, the infrastructure variables needed for the estimation are the number of telephone lines in service (fixed and mobile) as an indicator of telecommunications infrastructure; installed electric power as an indicator of the electricity sector; and an indicator of asphalt or paved roads, as a percentage of the total roads existing in each region.

For the estimations to reflect the true repercussion of infrastructure on output, the variables need to be adjusted for potential scale problems. For example, differences in population sizes between regions would justify a larger number of telephone lines in more populated regions, without this meaning greater relative capacity to provide a service and, therefore, does not lead to a higher rate of growth or size of output. Similarly, a longer length of the road network in larger regions would not necessarily mean higher productivity of this indicator compared with other regions.

As a result, the gross output value series — which is used as a proxy for GDP - was divided by the population of the region. This is the dependent variable used regularly in this type of studies and has been included in logarithms. Similarly, the telecommunications and electricity indicators are expressed in per capita terms for each region.

The transport infrastructure indicator was constructed as the quotient between the logarithm of the length of asphalt or paved road divided by the region's area, to correct for scale, and the logarithm of the length of the total road network also corrected for scale. This is a relative capacity indicator that takes into account not only differences in area, but also the difference in the quality of the road network. This indicator is not used in other studies, which instead use the logarithm of asphalt or paved roads divided by the surface area of the country in question. This indicator was chosen given the low variation displayed by the level of roads (total and asphalt) in relation to the areas of the Peruvian regions over the last decade. One of the main limitations of this choice is that it does not make it possible to compare the coefficient related to this type of infrastructure with those of electricity and telecommunications.

The other variables used, for control purposes, are the economically active population (EAP) adjusted for human capital, and the non-infrastructure capital stock. The first variable can be estimated through the EAP with secondary, higher, or both levels of schooling, or else with average years of schooling, which is the most widely used measure in international studies. This article used EAP with secondary or higher level schooling, owing to the lack of official statistics on the average years of schooling of the EAP in each region. It is also used as an alternative indicator to the EAP in levels, if the EAP with secondary schooling is not significant under some specifications. Both indicators were standardized by dividing them between the population of the region.

In the case of the non-infrastructure capital stock, the proxy variable constructed by Vásquez and Bendezú (2008) for 1973 and 1993 was used, and their methodology was used in constructing this variable for 2007 on the basis of the Fourth National Census performed by INEI. The methodology proposed by these authors consists of 
compiling the value of fixed assets of commercial and industrial firms (initial cost, revaluation and cumulative depreciation) at the regional level. The regional series for inter-census years was constructed according to the pattern of investment in each region.

Nonetheless, as this series includes private investment in electricity, telephony and roads (which could bias the results of the estimated model) these components were purged from it. For that purpose, a model was estimated through oLs, for which the dependent variable is estimated capital stock, and the explanatory variables are the three chosen infrastructure variables. The residual of that estimation is used as the proxy variable for noninfrastructure capital, after dividing it by the population and expressing it in logarithmic form.

For the estimated coefficients to be unbiased and efficient, the respective variables need to be stationary and not display any structural break. To detect these problems, the Levin, Lin and Chu (2002) and Im, Pesaran and Shin (2003) tests were performed, both developed in Cameron and Trivedi (2009). These tests use the null hypothesis that all panel data have a unit root. The Levin, Lin and Chu test assumes a single auto-regressive parameter for all panel data, in other words, a common unit root for all individuals (regions); so rejecting the null hypothesis could mean that some regions actually have series that display a unit root while other regions have the same series, but with stationary behaviour. The specification of the test for the existence of the individual intercept for each observation, but without trend, requires the number of periods to grow more quickly than that of the regions, so the ratio of regions to periods tends to zero, using augmented DickeyFuller tests for each region. Accordingly, rejecting the null hypothesis (at a 5\% significance level) means accepting that in no case is there a common unit root for all individuals.

In addition, as recommended by Canning (1999), to test the average stationarity of the series, a more powerful test was used than the augmented Dickey-Fuller test, through the sequential procedure of Dolado, Jenkinson, and Sosvilla-Rivero (1990) ${ }^{4}$ applied to each series for each individual (region). In this test of Im, Pesaran and Shin (2003) the Dickey-Fuller test was also used, but the t-statistics were averaged, so that the resultant t- statistic represents the average of independent stochastic trends ${ }^{5}$

4 Taken from Canning (1999).

5 In other words, it allows for the possibility that the panels do not have common unit roots. of a distribution with an expected value and known variance for a non-stationary series. Although this test is also designed for panel data in which there are more time periods than individuals, it is found to be very powerful also in short panels (Canning, 1999).

The results of applying the tests are not decisive in rejecting the null hypothesis of non-stationarity with respect to all variables. This is logical in a context where some infrastructures, such as mobile telephony, have made significant progress over the last decade in the Peruvian regions. This would be one of the main limitations of the estimations. Nonetheless, as the models in level terms do not include the lagged dependent variable, this would not be a relevant constraint. Moreover, the models in differences eliminate the unit root, solving the problem directly.

\section{Stylized facts of the Peruvian economy}

The sustained economic growth achieved by the Peruvian economy over the last decade has been the highest in the region and one of the highest worldwide. This growth is mainly due to the market reforms implemented in the 1990s, and has allowed for a significant reduction in poverty in Peru.

Nonetheless, one of the main problems that persists in the Peruvian economy is that production and economic development is concentrated in Lima and in the main coastal regions. This reflects the fact that efforts to decentralize productive activity and promote development in the mountain and jungle regions have been insufficient. In 2009, Lima accounted for $47 \%$ of the country's gross production value, followed by Arequipa, La Libertad and Piura with 5.2\%, 4.4\% and $3.7 \%$, respectively. One of the main challenges facing the Peruvian economy for the next decade is therefore to guarantee that productive development reaches the regions furthest from the capital.

However, some regions have achieved sustained economic growth thanks to the development of productive activities such as agribusiness (for example Ica and Lambayeque, which have very good climatic conditions and agricultural yields that are higher than most countries in the world) and mining and hydrocarbons (in particular Cusco with the Camisea natural gas project). Thus, the economic growth experienced by the regions of Peru has been differentiated, resulting in large disparities in current per capita GDP between regions (see figure 1).

This differentiated economic development is closely correlated with the relative presence of public infrastructures in each region. Various regions display 
FIGURE 1

Peru: Cumulative gdp growth, 2001-2009

(Percentage variation in real gdp, at 1994 prices)

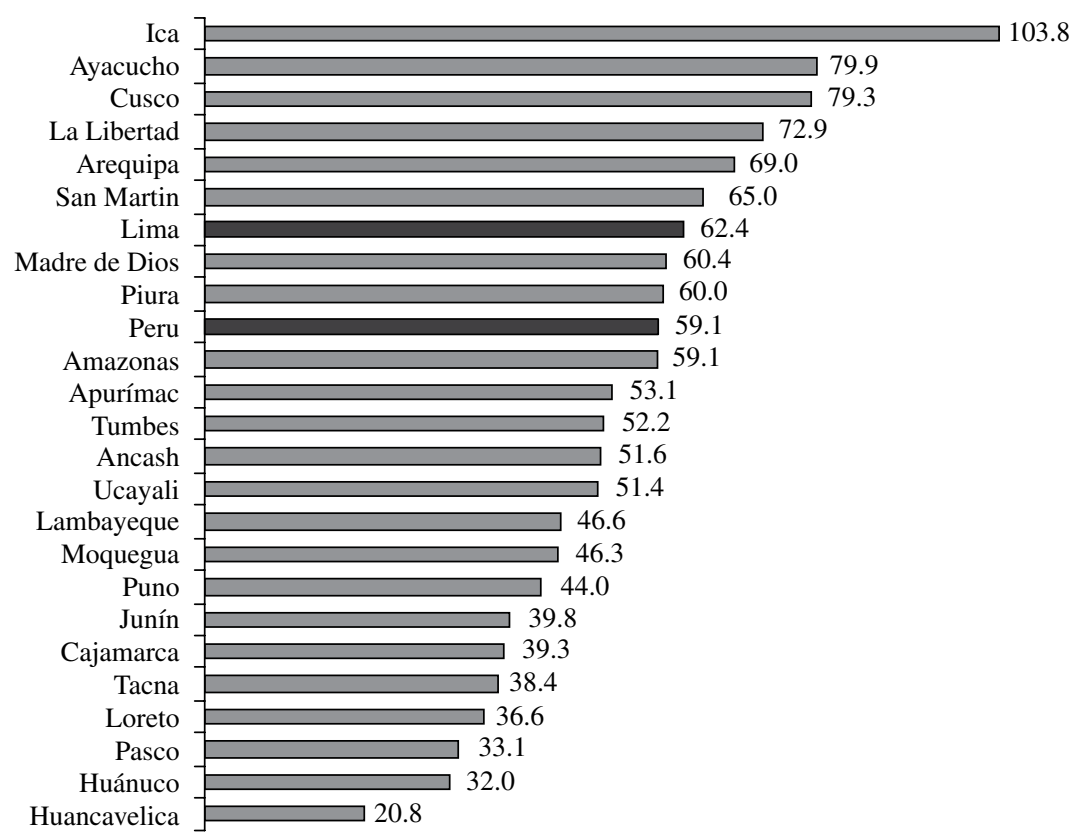

Source: prepared by the authors on the basis of data from the National Institute of Statistics and Information (INEI).

GDP: Gross domestic product.

large disparities in access to the different types of infrastructure, which constitutes one of the main obstacles to economic growth in the more remote localities of the country (see figure 2).

There is a positive correlation between the different types of infrastructure and per capita output in the various regions of Peru, particularly in the case of telecommunications and electric energy infrastructures. It is therefore worth analysing this relation using econometric techniques to find which type of infrastructure has the greatest effect on regional production and economic growth. 
FIGURE 2

Peru: Per capita gdp and infrastructure stock, 2009

Electric energy

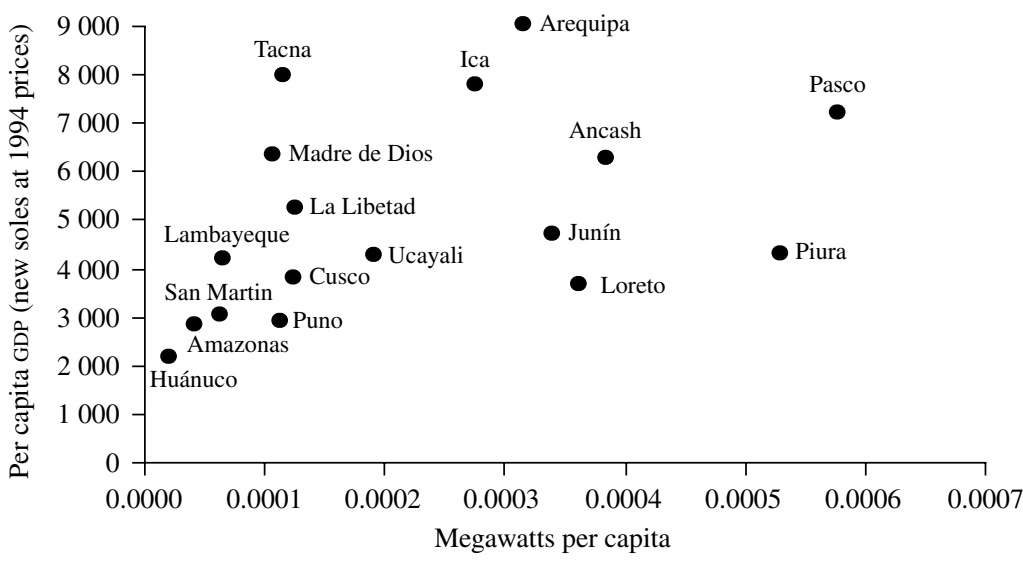

Roads

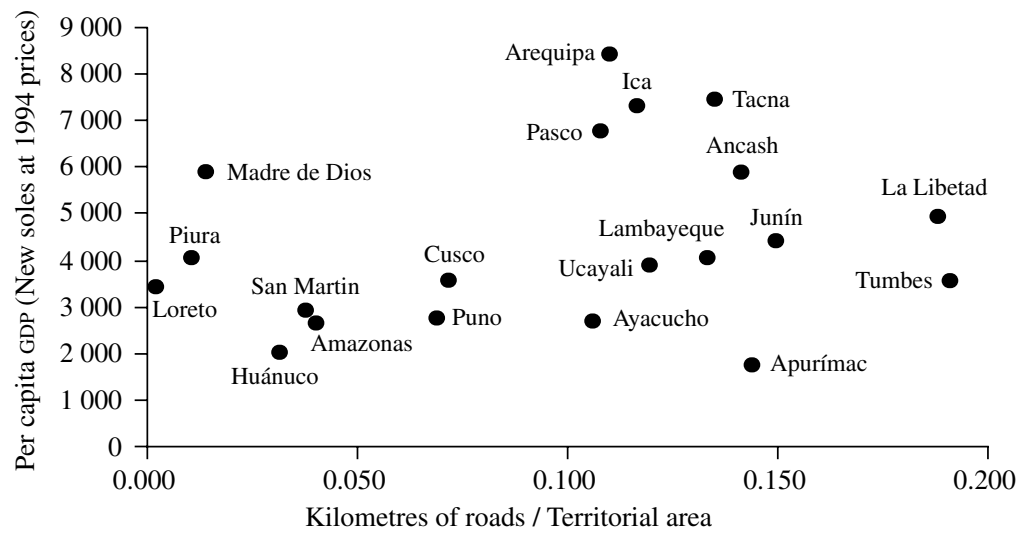

Telecommunications

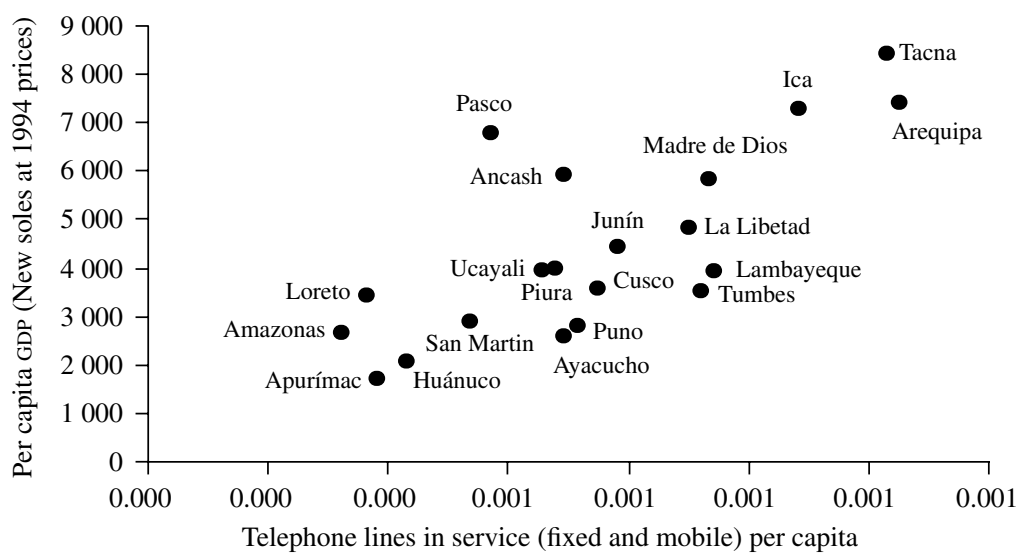

Source: prepared by the authors on the basis of data from the National Institute of Statistics and Information (INEI), the Supervisory Agency for Private Investment in Telecommunications (OsIPTEL), the Ministry of Energy and Mines (MINEM) and the Ministry of Transport and Communications (MTC).

Lima is excluded to avoid distorting the existing relation.

GDP: Gross domestic product. 


\section{IV}

\section{Analysis of results}

The estimated models have simultaneously considered indicators for the energy, transport and telecommunications sectors, as was also done by Canning (1999; Calderón and Servén (2004b); and Vásquez and Bendezú (2008). Nonetheless, this article has not controlled for the stage of the business cycle in which the regional economy is located, unlike the first study mentioned which uses controls to correct for that effect, and the second study, which uses a five-year moving average. The model was tested with the inclusion of the dummy time variables, but these proved not significant.

\section{Models in levels}

The first group of models uses per capita output as the dependent variable and is estimated in levels, which is consistent with neoclassical exogenous growth theory and evaluates the temporary effects of infrastructure on output. These models report the presence of a positive and significant effect for all infrastructures on per capita regional output. In addition, the relation prevails with all of the various estimators used, showing that the results are robust (there is no change in sign, and the magnitude of the coefficients are similar between specifications).

For these models, the educated EAP was not significant, but total EAP was significant, with the highest coefficient. This shows the importance of this input in regional production, compared with other productive factors (physical capital, human capital and infrastructures) (see table 2).

The per capita electricity stock has the greatest effect on regional per capita output. This result is logical because electricity is related directly to productive activity, whereas telecommunications are much more closely linked to worker productivity. Moreover, the telecommunications boom in Peru is a phenomenon of the last decade, so its repercussions would be diluted when the evaluation is performed over a longer horizon.

It is also important to note that both the electricity stock and telecommunications stock have a greater effect on regional output than non-infrastructure capital. This would suggest that the differentiated infrastructure stocks per capita in Peru's regions clearly explains the differences in regional per capita output. Thus, if the political authorities take steps to reduce the existing infrastructure gaps between the regions, progress can be made in reducing productive disparities.

Although the coefficient on the road stock indicator is not comparable with the coefficients of the other forms of infrastructure, this infrastructure explains much of the differences in regional production. One of the main problems at the regional level is the lack of roads and highways to bring markets closer to these localities. It is therefore important to prioritize investment in this infrastructure.

Each type of infrastructure explains the per capita output of each region in a different way. This may be due to the differences in the quality of regional infrastructure, the human capital in each region (which is not controlled for in the model, because the EAP did not prove significant), and other socioeconomic or political differences that might impose obstacles on the correct performance of infrastructures in certain regions. These differences explain how some regions can display greater or less than average effects for the different infrastructures on their respective output.

\section{Models in differences}

The second group of models uses the difference of per capita output as the dependent variable, as a function of differences in the model's explanatory variables. One of the main advantages of this specification is that is eliminates the unit roots encountered in the series. Against this, one of the main disadvantages is the loss of fit of the models through time (within-group $\mathrm{R}^{2}$ ), although there is a moderate fit between regions (between-groups $\mathrm{R}^{2}$ ) considering that it is a panel data model estimated in differences.

This result is consistent with the findings of Mankiw, Romer and Weil (1992), who argue that the empirical evidence supports neoclassical exogenous growth models. This explains the good fit of the models expressed in levels, compared to those expressed in differences. The loss of fit can be explained by the lack of regional controls (the dummy variables for each region proved insignificant) and to the elimination of the model's unobservable heterogeneity (by expressing the model in differences, making it time-invariant). When the model is estimated in differences, the latter is directly linked to regional 
TABLE 2

Model in logarithms of per capita gdp

\begin{tabular}{|c|c|c|c|c|c|c|c|}
\hline Variable & $\begin{array}{c}\text { Pooled data } \\
\text { (oLS estimator) }\end{array}$ & $\begin{array}{c}\text { Pooled data } \\
\text { (IV - GMM } \\
\text { estimator) }\end{array}$ & $\begin{array}{c}\text { Static panel } \\
\text { (GLS estimator) }\end{array}$ & Variable & $\begin{array}{c}\text { Pooled data } \\
\text { (oLS estimator) }\end{array}$ & $\begin{array}{c}\text { Pooled data } \\
\text { (IV - GMM } \\
\text { estimator) }\end{array}$ & $\begin{array}{c}\text { Static panel } \\
\text { (GLS estimator) }\end{array}$ \\
\hline Constant & $\begin{array}{l}10.9779 * * * \\
(0.1243)\end{array}$ & $\begin{array}{l}10.8915^{* * *} \\
(0.1470)\end{array}$ & $\begin{array}{l}10.9084 * * * \\
(0.3199)\end{array}$ & $\begin{array}{l}\text { Telecommunications } \\
\text { (continued) }\end{array}$ & & & \\
\hline Log [ Regional capital] & $\begin{array}{l}0.0607 * * * \\
(0.0123)\end{array}$ & $\begin{array}{l}0.0591^{* * * *} \\
(0.0117)\end{array}$ & $\begin{array}{c}0.0543 \\
(0.0379)\end{array}$ & $\begin{array}{l}\text { Log [telecom indicator] } \\
\text { *Madre_de_Dios }\end{array}$ & $\begin{array}{l}-0.0900 * * * \\
(0.0110)\end{array}$ & $\begin{array}{l}-0.0956^{* * *} \\
(0.0119)\end{array}$ & $\begin{array}{l}-0.0744^{* * * *} \\
(0.0230)\end{array}$ \\
\hline $\log [\mathrm{EAP}]$ & $\begin{array}{l}1.3737 * * * \\
(0.1281)\end{array}$ & $\begin{array}{l}1.2960^{* * * *} \\
(0.1464)\end{array}$ & $\begin{array}{l}1.4260 * * * \\
(0.3023)\end{array}$ & $\begin{array}{l}\text { Log [Telecom indicator] } \\
\text { *Pasco }\end{array}$ & $\begin{array}{l}-0.1397 * * * \\
(0.0078)\end{array}$ & $\begin{array}{l}-0.1405^{* * *} \\
(0.0076)\end{array}$ & $\begin{array}{l}-0.1358^{* * * *} \\
(0.0115)\end{array}$ \\
\hline Electricity & & & & $\begin{array}{l}\text { Log [Telecom indicator] } \\
\text { *Piura }\end{array}$ & $\begin{array}{l}0.0590 * * * \\
(0.0143)\end{array}$ & $\begin{array}{l}0.0591 * * * \\
(0.0141)\end{array}$ & $\begin{array}{l}0.0589 * * * \\
(0.0144)\end{array}$ \\
\hline Log [Electricity indicator] & $\begin{array}{l}0.1268 * * * \\
(0.0091)\end{array}$ & $\begin{array}{l}0.1265^{* * *} \\
(0.0089)\end{array}$ & $\begin{array}{l}0.1139 * * * \\
(0.0206)\end{array}$ & $\begin{array}{l}\text { Log [Telecom indicator] } \\
\text { *Puno }\end{array}$ & $\begin{array}{l}0.0470 * * * \\
(0.0080)\end{array}$ & $\begin{array}{l}0.0460 * * * \\
(0.0077)\end{array}$ & $\begin{array}{l}0.0569 * * * \\
(0.0129)\end{array}$ \\
\hline $\begin{array}{l}\text { Log [Electricity indicator] } \\
\text { *Amazonas }\end{array}$ & & & $\begin{array}{l}0.0705^{* * * *} \\
(0.0202)\end{array}$ & $\begin{array}{l}\text { Log [Telecom indicator] } \\
\text { *San_Martin }\end{array}$ & $\begin{array}{l}-0.0646^{* * *} * \\
(0.0174)\end{array}$ & $\begin{array}{l}-0.0655^{* * * *} \\
(0.0168)\end{array}$ & $\begin{array}{l}-0.0581^{* * * *} \\
(0.0123)\end{array}$ \\
\hline $\begin{array}{l}\text { Log [Electricity indicator] } \\
\text { *Apurimac }\end{array}$ & $\begin{array}{l}0.0101^{* * *} \\
(0.0038)\end{array}$ & $\begin{array}{l}0.0112^{* * * *} \\
(0.0038)\end{array}$ & $\begin{array}{l}0.0132 * * * \\
(0.0051)\end{array}$ & $\begin{array}{l}\text { Log [Telecom indicator] } \\
\text { *Tacna }\end{array}$ & $\begin{array}{l}-0.2243 * * * \\
(0.0106)\end{array}$ & $\begin{array}{l}-0.1801^{* * *} \\
(0.0209)\end{array}$ & $\begin{array}{l}-0.2245^{* * * *} \\
(0.0219)\end{array}$ \\
\hline $\begin{array}{l}\text { Log [Electricity indicator] } \\
\text { *Cajamarca }\end{array}$ & $\begin{array}{l}0.0478 * * * \\
(0.0136)\end{array}$ & $\begin{array}{l}0.0475^{* * *} \\
(0.0131)\end{array}$ & $\begin{array}{l}0.0541 * * * \\
(0.0112)\end{array}$ & Transport & & & \\
\hline $\begin{array}{l}\text { Log [Electricity indicator] } \\
*^{*} \text { Cusco }\end{array}$ & $\begin{array}{l}0.0223^{* * * *} \\
(0.0030)\end{array}$ & $\begin{array}{l}0.0220 * * * \\
(0.0030)\end{array}$ & $\begin{array}{l}0.0242 * * * \\
(0.0029)\end{array}$ & Log [ Transport indicator] & $\begin{array}{l}0.0395 * * * \\
(0.0055)\end{array}$ & $\begin{array}{l}0.0385^{* * *} \\
(0.0054)\end{array}$ & $\begin{array}{l}0.0331 * * \\
(0.0156)\end{array}$ \\
\hline $\begin{array}{l}\text { Log [Electricity indicator] } \\
\text { *Huánuco }\end{array}$ & $\begin{array}{l}0.0163 * * * \\
(0.0036)\end{array}$ & $\begin{array}{l}0.0171^{* * *} \\
(0.0034)\end{array}$ & $\begin{array}{l}0.0201 * * * \\
(0.0068)\end{array}$ & $\begin{array}{l}\text { Log [Transport indicator] } \\
\text { *Amazonas }\end{array}$ & & & $\begin{array}{l}-0.2428 * * * \\
(0.063)\end{array}$ \\
\hline $\begin{array}{l}\text { Log [Electricity indicator] } \\
\text { *Ica }\end{array}$ & $\begin{array}{l}-0.1226 * * * \\
(0.0452)\end{array}$ & $\begin{array}{l}-0.1160^{* * * *} \\
(0.0442)\end{array}$ & $\begin{array}{l}-0.1184 * * * \\
(0.0398)\end{array}$ & $\begin{array}{l}\text { Log [Transport indicator] } \\
\text { *Cajamarca }\end{array}$ & $\begin{array}{l}-0.4364 * * * \\
(0.1493)\end{array}$ & $\begin{array}{l}-0.4309^{* * * *} \\
(0.1444)\end{array}$ & $\begin{array}{l}-0.4908^{* * * *} \\
(0.1423)\end{array}$ \\
\hline $\begin{array}{l}\text { Log [Electricity indicator] } \\
* \text { Moquegua }\end{array}$ & $\begin{array}{l}-0.0935 * * * \\
(0.0068)\end{array}$ & $\begin{array}{l}-0.0964 * * * \\
(0.0069)\end{array}$ & $\begin{array}{l}-0.0972 * * * \\
(0.0152)\end{array}$ & $\begin{array}{l}\text { Log [Transport indicator }] \\
\text { *Ica }\end{array}$ & $\begin{array}{l}0.6401^{* *} \\
(0.2959)\end{array}$ & $\begin{array}{l}0.5926^{* *} \\
(0.2895)\end{array}$ & $\begin{array}{l}0.6207 * * * \\
(0.2616)\end{array}$ \\
\hline $\begin{array}{l}\text { Log [Electricity indicator] } \\
\text { *San_Martín }\end{array}$ & $\begin{array}{l}0.0389 * * * \\
(0.0067)\end{array}$ & $\begin{array}{l}0.0381^{* * * *} \\
(0.0065)\end{array}$ & $\begin{array}{l}0.0421^{* * * *} \\
(0.0078)\end{array}$ & $\begin{array}{l}\text { Log [Transport indicator }] \\
\text { *Lima }\end{array}$ & $\begin{array}{l}-1.3135^{* * * *} \\
(0.1973)\end{array}$ & $\begin{array}{l}-1.3913^{* * *} \\
(0.2112)\end{array}$ & $\begin{array}{l}-1.3060 * * * \\
(0.2890)\end{array}$ \\
\hline Telecommunications & & & & $\begin{array}{l}\text { Log [Transport indicator] } \\
\text { *Piura }\end{array}$ & $\begin{array}{l}-0.3007 * * * \\
(0.0613)\end{array}$ & $\begin{array}{l}-0.3002 * * * \\
(0.0603)\end{array}$ & $\begin{array}{l}-0.2927 * * * \\
(0.0212)\end{array}$ \\
\hline Log [Telecom indicator] & $\begin{array}{l}0.0757 * * * \\
(0.0077)\end{array}$ & $\begin{array}{l}0.0786^{* * * *} \\
(0.0078)\end{array}$ & $\begin{array}{l}0.0680 * * * \\
(0.0178)\end{array}$ & $\begin{array}{l}\text { Log [Transport indicator }] \\
\text { *Tacna }\end{array}$ & & $\begin{array}{l}-0.0838 * * * \\
(0.0344)\end{array}$ & \\
\hline $\begin{array}{l}\text { Log [Telecom indicator }] \\
\text { *Arequipa }\end{array}$ & $\begin{array}{l}-0.0951 * * * \\
(0.0107)\end{array}$ & $\begin{array}{l}-0.0986^{* * * *} \\
(0.0112)\end{array}$ & $\begin{array}{l}-0.0938 * * * \\
(0.0142)\end{array}$ & $\begin{array}{l}\text { Number of observations } \\
\mathrm{R}^{2}\end{array}$ & $\begin{array}{c}480 \\
0.9411\end{array}$ & $\begin{array}{c}480 \\
0.9414\end{array}$ & 480 \\
\hline $\begin{array}{l}\text { Log [Telecom indicator] } \\
\text { *Huánuco }\end{array}$ & $\begin{array}{l}-0.0332 * * * \\
(0.0100)\end{array}$ & $\begin{array}{l}-0.0345^{* * * *} \\
(0.0097)\end{array}$ & $\begin{array}{l}-0.0326 * * * \\
(0.0108)\end{array}$ & $\begin{array}{l}\text { Within-group } \mathrm{R}^{2} \\
\text { Between-groups } \mathrm{R}^{2}\end{array}$ & & & $\begin{array}{l}0.6133 \\
0.9922\end{array}$ \\
\hline $\begin{array}{l}\text { Log [Telecom indicator] } \\
\text { *Loreto }\end{array}$ & $\begin{array}{l}-0.0954 * * * \\
(0.0104)\end{array}$ & $\begin{array}{l}-0.0934 * * * \\
(0.0103)\end{array}$ & $\begin{array}{l}-0.0827 * * * \\
(0.0259)\end{array}$ & Average $\mathrm{R}^{2}$ & & & 0.9431 \\
\hline
\end{tabular}

Source: prepared by the authors on the basis of data from the National Institute of Statistics and Information (INEI), the Supervisory Agency for Private Investment in Telecommunications (OSIPTEL), the Ministry of Energy and Mines (MINEM) and the Ministry of Transport and Communications (MTC); and information from Vásquez and Bendezú, Ensayos sobre el rol de la infraestructura vial en el crecimiento económico del Perú, Lima, Economic and Social Research Consortium (CIES )/Central Reserve Bank of Peru (BCRP), 2008.

GDP: Gross domestic product. EAP: economically active population. Log: logarithm. OLs: Ordinary least squares.

GLS: generalized least squares.

Instrumental variables estimator (IV) through the generalized method of moments (GMM).

Standard errors in parentheses (robust).

$* \mathrm{p}<0.10, * * \mathrm{p}<0.05, * * * \mathrm{p}<0.01$ 
productivity according to the model's specification, which would capture the main differences in regional economic growth. This would also indicate that infrastructure, human capital and non-infrastructure physical capital partly fail to explain differences in long-term regional growth.

This evidence also suggests that other factors are more important in explaining the differences. One of these could be the almost non-existent decentralization of production. In addition, the presence of hydrocarbon, mining, or agro-export projects in some regions will also explain the differences. Productive activities related to these sectors have been promoted during the last few years owing to the high international prices of certain agro-export, hydrocarbon and mineral products. All of this suggest that infrastructure would not have a long-term effect on economic activity or on long-term economic growth (see table 3).

As in the case of models expressed in levels, models in differences report the presence of a positive and significant effect of all infrastructures on regional

TABLE 3

Model in differences of per capita gdp growth

\begin{tabular}{|c|c|c|c|c|c|}
\hline Variable & $\begin{array}{l}\text { Pooled data } \\
\text { (IV-GMM } \\
\text { estimator) }\end{array}$ & $\begin{array}{c}\text { Static panel } \\
\text { (GLS estimator) }\end{array}$ & $\begin{array}{l}\text { Static panel } \\
\text { (within-group } \\
\text { estimator) }\end{array}$ & $\begin{array}{l}\text { Dynamic panel } \\
\text { (GMM estimator) }\end{array}$ & $\begin{array}{c}\text { Dynamic panel } \\
\text { (system GMM } \\
\text { estimator) }\end{array}$ \\
\hline Constant & $\begin{array}{l}-0.0288 * * * \\
(0.0074)\end{array}$ & $\begin{array}{l}-0.0272 * * * \\
(0.0062)\end{array}$ & $\begin{array}{l}-0.0613 * * * \\
(0.0107)\end{array}$ & $\begin{array}{l}-0.0155 \\
(0.0382)\end{array}$ & $\begin{array}{l}-0.0831 * * \\
(0.0406)\end{array}$ \\
\hline$\Delta \log [$ Per capita GDP (t-1)] & & & & $\begin{array}{l}-0.1299 * * * \\
(0.0287)\end{array}$ & $\begin{array}{l}-0.1805^{* * * *} \\
(0.0574)\end{array}$ \\
\hline$\Delta$ Log [EAP with human capital] & $\begin{array}{l}0.4666^{* *} \\
(0.2193)\end{array}$ & $\begin{array}{l}0.4097 * * * \\
(0.1542)\end{array}$ & $\begin{array}{l}1.5109^{* * * *} \\
(0.3781)\end{array}$ & $\begin{array}{c}0.3319 \\
(1.2691)\end{array}$ & $\begin{array}{l}2.2662 * \\
(1.3284)\end{array}$ \\
\hline$\Delta \log [$ regional capital] & $\begin{array}{l}0.1050 * * * \\
(0.0324)\end{array}$ & $\begin{array}{l}0.1067 * * * \\
(0.0421)\end{array}$ & $\begin{array}{l}0.1173 * * \\
(0.0444)\end{array}$ & $\begin{array}{c}0.0955^{*} \\
(0.0510)\end{array}$ & $\begin{array}{l}0.1278 * * \\
(0.0560)\end{array}$ \\
\hline$\Delta \log$ [electricity indicator] & $\begin{array}{l}0.0911^{* * * *} \\
(0.0247)\end{array}$ & $\begin{array}{l}0.0919 * * * \\
(0.0322)\end{array}$ & $\begin{array}{l}0.0997 * * * \\
(0.0341)\end{array}$ & $\begin{array}{l}0.0889 * * * \\
(0.0274)\end{array}$ & $\begin{array}{l}0.1129 * * * \\
(0.0286)\end{array}$ \\
\hline$\Delta \log [$ telecom indicator $]$ & $\begin{array}{l}0.1209 * * * \\
(0.0220)\end{array}$ & $\begin{array}{l}0.1224 * * * \\
(0.0244)\end{array}$ & $\begin{array}{l}0.1204 * * * \\
(0.0278)\end{array}$ & $\begin{array}{l}0.0831 * * * \\
(0.0307)\end{array}$ & $\begin{array}{l}0.1141 * * * \\
(0.0354)\end{array}$ \\
\hline$\Delta \log [$ transport indicator $]$ & $\begin{array}{c}0.0463 * \\
(0.0275)\end{array}$ & $\begin{array}{l}0.0464 * * * \\
(0.0288)\end{array}$ & $\begin{array}{l}0.0574 * * * \\
(0.0303)\end{array}$ & $\begin{array}{l}0.0921 * * * \\
(0.0168)\end{array}$ & $\begin{array}{l}0.0871 * * * \\
(0.0176)\end{array}$ \\
\hline Number of observations & 717 & 717 & 717 & 693 & 695 \\
\hline $\mathrm{R}^{2}$ & 0.0748 & - & - & - & - \\
\hline Within-group $\mathrm{R}^{2}$ & - & 0.0787 & 0.0862 & - & - \\
\hline Between-groups $\mathrm{R}^{2}$ & - & 0.1190 & 0.1085 & - & - \\
\hline Average $\mathrm{R}^{2}$ & - & 0.0749 & 0.0609 & - & - \\
\hline Sargan statistic & - & - & - & 1.00 & 1.00 \\
\hline $\begin{array}{l}\text { Arellano-Bond (first-order } \\
\text { autocorrelation test) }\end{array}$ & - & - & - & 0.0006 & 0.0009 \\
\hline $\begin{array}{l}\text { Arellano-Bond (second-order } \\
\text { autocorrelation test) }\end{array}$ & - & - & - & 0.4604 & 0.7371 \\
\hline
\end{tabular}

Source: Prepared by the authors on the basis of data from the National Institute of Statistics and Information (INEI), the Supervisory Agency for Private Investment in Telecommunications (osIPTEL), the Ministry of Energy and Mines (MINEM) and the Ministry of Transport and Communications (MTC); and information from Vásquez and Bendezú, Ensayos sobre el rol de la infraestructura vial en el crecimiento económico del Perú, Lima, Economic and Social Research Consortium (CIES )/Central Reserve Bank of Peru (BCRP), 2008.

Standard errors in parentheses (robust).

$\mathrm{p}<0.10 ; * * \mathrm{p}<0.05 ; * * * \mathrm{p}<0,01$.

GLS: generalized least squares.

Instrumental variables estimator (IV) through the generalized method of moments (GMM). 
growth. Moreover, this relation prevails in all of the various estimators used, showing that the results are robust.

These models also find that lagged per capita output growth has a significant effect on contemporary growth, but with a negative sign. This reflects the fact that several regions do not have sustained growth, which suggests the need to develop regional infrastructure more to eliminate the obstacles to sustained growth. In particular, steps must be taken to avoid regional economic growth depending on isolated projects, which are governed by the volatility of prices on international markets.

In these models, the educated EAP was significant, showing that human capital is important for long-term regional economic growth. Nonetheless, as the average education level of the population in the regions is lower, this factor is not yet as important as might be expected.
In these models, the relative importance of infrastructures is reversed, and it is now telecommunications that explains most of the effects on economic growth. This reflects the fact that telecommunications are more closely linked to worker productivity (human capital), which is a determinant of long-term regional growth; the development of electricity projects would be much more closely related to short-term variations in regional output. In any event, the electricity and telecommunications variables both have repercussions on regional growth that are similar to those of non-infrastructure capital.

Lastly, the roads indicator explains much of the differences in regional growth; and the development of this infrastructure is more important in reducing disparities in long-term growth between regions than in explaining the temporary gaps in regional output.

\section{$\mathrm{V}$}

\section{Conclusions and recommendations}

This study shows that public-service infrastructures are important in explaining disparities in regional per capita output in Peru, which is consistent not only with theory, but also with most of the studies undertaken in numerous countries.

The evidence supports the presence of significant differences in the repercussions of the different infrastructures - mainly electricity and telecommunications - on the per capita output of each region, which can be explained by differences in the quality of regional infrastructure. Accordingly, the political authorities need to focus on increasing the quantity and improving the quality of infrastructures and maintaining them adequately.

Nonetheless, the evidence is not conclusive regarding the incidence of infrastructure on long-term regional economic growth. Other factors would be more important in explaining the differences: human capital, technological progress, productive decentralization, among others. Accordingly, for infrastructure to have long-term repercussions on regional growth, complementary policies are needed to reduce regional gaps.

The main policy implication to arise from the analysis is the need to persevere in developing publicservice infrastructure. The authorities should speed up pending concession processes and allow private initiatives that require some degree of co-financing — obviously provided the project displays economic and social benefits in excess of its costs. Similarly, the different levels of government should assign greater budgetary funding to implement or finance this type of project than previously has been approved by the National Public Investment System.

A region can enjoy faster growth and a higher per capita output level if it invests resources in a timely and efficient manner to improve its road, telecommunications and electricity infrastructures. It is therefore unjustifiable that Peru has a group of regional and municipal governments with very low levels of budgetary execution, mainly in infrastructure, and that many of them are precisely in the country's most depressed zones.

Nonetheless, the numerical results need to be used with caution owing to problems of information quality at the regional level. For that reason, greater efforts should be made to review the information that is currently available, and to produce and process the information that has been identified as necessary to obtain more reliable results. This poses an additional challenge for the authorities, or more specifically for the institutions that produce and manage the statistics, although, as potential users of the information, the universities and research centres should also commit their support.

(Original: Spanish) 
APPENDIX

Statistics of the variables used

\begin{tabular}{|c|c|c|c|c|c|c|}
\hline Variable & Variability & Mean & $\begin{array}{l}\text { Standard } \\
\text { deviation }\end{array}$ & Minimum & Maximum & $\begin{array}{l}\text { Number of } \\
\text { observations }\end{array}$ \\
\hline Per capita GDP ${ }^{\mathrm{a}}$ & $\begin{array}{l}\text { Average } \\
\text { Between groups } \\
\text { Within groups }\end{array}$ & 3907.8 & $\begin{array}{ll}2 & 455.9 \\
2 & 229.4 \\
1 & 108.8\end{array}$ & $\begin{array}{rl}1 & 216.2 \\
1 & 638.0 \\
-4 & 639.0\end{array}$ & $\begin{array}{r}16133.3 \\
10447.8 \\
9593.3\end{array}$ & 928 \\
\hline EAP per capita & $\begin{array}{l}\text { Average } \\
\text { Between groups } \\
\text { Within groups }\end{array}$ & 0312.0 & $\begin{array}{ll}0 & 043.5 \\
0 & 034.6 \\
0 & 027.1\end{array}$ & $\begin{array}{ll}0 & 230.7 \\
0 & 255.8 \\
0 & 221.4\end{array}$ & $\begin{array}{ll}0 & 478.3 \\
0 & 407.2 \\
0 & 443.7\end{array}$ & 903 \\
\hline $\begin{array}{l}\text { EAP with secondary or higher } \\
\text { education per capita }^{\text {a }}\end{array}$ & $\begin{array}{l}\text { Average } \\
\text { Between groups } \\
\text { Within groups }\end{array}$ & 0154.6 & $\begin{array}{ll}0 & 075.6 \\
0 & 059.4 \\
0 & 048.3\end{array}$ & $\begin{array}{ll}0 & 028.3 \\
0 & 073.7 \\
0 & 057.3\end{array}$ & $\begin{array}{ll}0 & 398.3 \\
0 & 295.9 \\
0 & 354.1\end{array}$ & 890 \\
\hline $\begin{array}{l}\text { Regional non-infrastructure } \\
\text { capital per capita }\end{array}$ & $\begin{array}{l}\text { Average } \\
\text { Between groups } \\
\text { Within groups }\end{array}$ & 0000.3 & $\begin{array}{ll}0 & 000.6 \\
0 & 000.6 \\
0 & 000.1\end{array}$ & $\begin{array}{rr}0 & 000.1 \\
0 & 000.0 \\
-0 & 000.9\end{array}$ & $\begin{array}{ll}0 & 002.9 \\
0 & 002.3 \\
0 & 001.0\end{array}$ & 812 \\
\hline Electricity per capita $^{\mathrm{b}}$ & $\begin{array}{l}\text { Average } \\
\text { Between groups } \\
\text { Within groups }\end{array}$ & 0090.2 & $\begin{array}{ll}0 & 199.1 \\
0 & 054.1 \\
0 & 191.8\end{array}$ & $\begin{array}{rr}0 & 000.2 \\
0 & 013.5 \\
-0 & 103.3\end{array}$ & $\begin{array}{ll}1 & 393.2 \\
0 & 237.4 \\
1 & 246.0\end{array}$ & 823 \\
\hline Telecommunications per capita ${ }^{c}$ & $\begin{array}{l}\text { Average } \\
\text { Between groups } \\
\text { Within groups }\end{array}$ & 0002.4 & $\begin{array}{ll}0 & 007.9 \\
0 & 004.6 \\
0 & 006.5\end{array}$ & $\begin{array}{rr}0 & 000.0 \\
0 & 000.1 \\
-0 & 018.7\end{array}$ & $\begin{array}{ll}0 & 119.8 \\
0 & 023.1 \\
0 & 099.1\end{array}$ & 888 \\
\hline Transport $^{\mathrm{d}}$ & $\begin{array}{l}\text { Average } \\
\text { Between groups } \\
\text { Within groups }\end{array}$ & 0432.9 & $\begin{array}{l}0558.6 \\
0525.9 \\
0215.3\end{array}$ & $\begin{array}{r}0000.7 \\
0001.3 \\
-1007.9\end{array}$ & $\begin{array}{l}3977.8 \\
2640.3 \\
1770.4\end{array}$ & 742 \\
\hline
\end{tabular}

Source: prepared by the authors on the basis of data from the National Institute of Statistics and Information (INEI), the Supervisory Agency for Private Investment in Telecommunications (OSIPTEL), the Ministry of Energy and Mines (MINEM) and the Ministry of Transport and Communications (мтс); and information from Vásquez and Bendezú, Ensayos sobre el rol de la infraestructura vial en el crecimiento económico del Perú, Lima, Economic and Social Research Consortium (CIES )/Central Reserve Bank of Peru (BCRP), 2008.

a Soles at 1994 prices.

b Megawatts.

c Fixed and mobile lines.

d Quality indicator between the stock of road networks.

GDP: Gross domestic product. EAP: economically active population.

\section{Bibliography}

Alesina, A. and R. Perotti (1993), "Income distribution, political instability, and investment", nber Working Paper, No. 4486, Cambridge, Massachusetts, National Bureau of Economic Research.

Arellano, M. and S. Bond (1991), "Some tests of specification for panel data: Monte Carlos evidence and an application to employment equations", Review of Economic Studies, vol. 58, No. 2, Wiley Blackwell.

Arellano, M. and O. Bover (1995), "Another look at the instrumental variable estimation of error-component models", Journal of Econometrics, vol. 68, No. 1, Amsterdam, Elsevier.

Aschauer, D. (1989), "Is public expenditure productive?", Journal of Monetary Economics, vol. 23, No. 2, Amsterdam, Elsevier.

Bandyopadhyay, S. and S. Devarajan (1993), "Using project rates of return to inform sector allocation decisions", Washington, D.C., World Bank, unpublished.

Barro, R. and X. Sala-i-Martin (1990), "Public finance in models of economic growth", nber Working Paper, No. 3362, Cambridge, Massachusetts, National Bureau of Economic Research.

Blundell, R. and S. Bond (1998), "Initial conditions and moment restrictions in dynamic panel data models", Journal of Econometrics, vol. 87, No. 1, Amsterdam, Elsevier.
Calderón, C. and L. Servén (2004a), "Trends in infrastructure in Latin America, 1980-2001”, Working Papers, No. 269, Santiago, Chile, Central Bank of Chile, September.

(2004b), "The effects of infrastructure development on growth and income distribution", Working Papers, No. 270, Santiago, Chile, Central Bank of Chile, September.

Cameron, C. and P. Trivedi (2009), Microeconometrics Using Stata, Texas, Stata Press.

Canning, D. (1999), "Infrastructure's contribution to aggregate output”, Policy Research Working Paper, No. 2246, Washington, D.C., World Bank.

Canning, D. and E. Bennathan (2000), "The social rate of return on infrastructure investments", Policy Research Working Paper, No. 2390, Washington, D.C., World Bank.

Canning, D. and P. Pedroni (2004), "The effect of infrastructure on long run economic growth", November, unpublished.

Cárdenas, M., A. Gaviria and M. Meléndez (2005), "La infraestructura de transporte en Colombia", August, unpublished.

Davis, D. (1998), "The home market, trade and industrial structure", American Economic Review, vol. 88, No. 5, Nashville, Tennessee, American Economic Association, December. 
Devarajan, S., V. Swaroop and H. Zou (1996), "The composition of public expenditure and economic growth", Journal of Monetary Economics, vol. 37, No. 2-3, Amsterdam, Elsevier.

Dolado, J., T. Jenkinson and S. Sosvilla-Rivero (1990), "Cointegration and unit root tests", Journal of Economic Surveys, vol. 4, No. 3, Wiley.

Duggal, V., C. Saltzman and L. Klein (1999), "Infrastructure and productivity: a nonlinear approach", Journal of Econometrics, vol. 92, No. 1, Amsterdam, Elsevier.

Easterly, W. and S. Rebelo (1993), "Fiscal policy and economic growth: An empirical investigation", Journal of Monetary Economics, vol. 32, No. 4, Amsterdam, Elsevier.

Esfahani, H. and M. Ramírez (2003), "Institutions, infrastructure and economic growth", Journal of Development Economics, vol. 70, No. 2, Amsterdam, Elsevier.

Estache, A. and M. Fay (2007), "Current debates on infrastructure policy", Policy Research Working Paper, No. 4410, Washington, D.C., World Bank, November.

Fay, M. and M. Morrison (2005), Infrastructure in Latin America and the Caribbean: recent developments and key challenges, Washington, D.C., World Bank.

García-Milà, T., T. McGuire and R. Porter (1996), "The effect of public capital in state-level production functions reconsidered", Review of Economics and Statistics, vol. 78, No. 1, Cambridge, Massachusetts, The MIT Press.

Glomm, G. and B. Ravikumar (1994), "Public investment in infrastructure in a simple growth model", Journal of Economic Dynamics and Control, vol. 18, No. 6, Amsterdam, Elsevier.

González, J., J. Guasch and T. Serebrisky (2007), "Latin America: Addressing high logistics costs and poor infrastructure for merchandise transportation and trade facilitation", Consulta de San José 2007, World Bank, August.

Gramlich, E. (1994), "Infrastructure investment: A review essay", Journal of Economic Literature, vol. 32, No. 3, Nashville, Tennessee, American Economic Association.

Guasch, J., J. Laffont and S. Straub (2005), "Infrastructure concessions in Latin America: government-led renegotiations", Policy Research Working Paper, No. 3749, Washington, D.C., World Bank.

Holtz-Eakin, D. (1994), "Public-sector capital and the productivity puzzle", Review of Economics and Statistics, vol. 76, No. 1, Cambridge, Massachusetts, The MIT Press.

Hulten, C. (1996), "Infrastructure capital and economic growth: How well you use it may be more important than how much you have", nber Working Paper, No. 5847, Cambridge, Massachusetts, National Bureau of Economic Research.

Hulten, C., E. Bennathan and S. Srinivasan (2006), "Infrastructure, externalities, and economic development", World Bank Economic Review, vol. 20, No. 2, Washington, D.C., World Bank.

Im, K., M.H. Pesaran and Y. Shin (2003), "Testing for unit roots in heterogeneous panels", Journal of Econometrics, vol. 115, No. 1, Amsterdam, Elsevier.

Laffont, J. and J. Tirole (1993), A Theory of Incentives in Procurement and Regulation, Cambridge, Massachusetts, The MIT Press.

Levin, A., Ch. Lin and Ch. Chu (2002), "Unit root tests in panel data: Asymptotic and finite-sample properties", Journal of Political Economy, vol. 108, No. 1, Amsterdam, Elsevier.

Limao, N. and A. Venables (2001), "Infrastructure, geographical disadvantage, transport costs and trade", World Bank Economic Review, vol. 15, No. 3, Washington, D.C., World Bank.

Limi, A. (2008), "Effects of improving infrastructure quality on business costs: Evidence from firm-level data", Policy Research Working Paper, No. 4581, Washington, D.C., World Bank, March.
Loayza, N., P. Fajnzylber and C. Calderón (2002), Economic Growth in Latin America and the Caribbean: Stylized Facts, Explanations, and Forecasts, Washington, D.C., World Bank, June.

Mankiw, G., D. Romer and D. Weil (1992), "A contribution to the empirics of economic growth", The Quarterly Journal of Economics, vol. 107, No. 2, Cambridge, Massachusetts, The MIT Press, May.

Mia, I., J. Estrada and T. Geiger (2007), Benchmarking National Attractiveness for Private Investment in Latin American Infrastructure, World Economic Forum.

Munnell, A. (1990), "Why has productivity growth declined? Productivity and public investment", New England Economic Review, Boston, Federal Reserve Bank of Boston, JanuaryFebruary.

Nadiri, M. Ishaq and T. Mamuneas (1994), "Infrastructure and public R\&D investments, and the growth of factor productivity in US manufacturing industries", nber Working Paper, No. 4845, Cambridge, Massachusetts, National Bureau of Economic Research, August.

Noriega, A. and M. Fontela (2005), "Public infrastructure and economic growth in Mexico", University of Guanajato/ Economic Research and Teaching Centre (CIDE), April, unpublished.

Pritchett, L. (1996), "Mind your P's and Q's. The cost of public investment is not the value of public capital", Policy Research Working Paper, No. 1660, Washington, D.C., World Bank.

Prud'homme, R. (2005), "Infrastructure and development", Аnnual World Bank Conference on Development Economics, 2005: Lessons of Experience, F. Bourguignon and B. Pleskovic (eds.), Washington, D.C., World Bank/Oxford University Press.

Rivera, J. and P. Toledo (2004), "Efectos de la infraestructura pública sobre el crecimiento de la economía, evidencia para Chile", Estudios de economía, vol. 31, Santiago, Chile, University of Chile.

Romp, W. and J. de Haan (2007), "Public capital and economic growth: A critical survey", Perspektiven der Wirtschaftspolitik, vol. 8, Blackwell Publishing.

Sánchez-Robles, B. (1998), "Infrastructure investment and growth: Some empirical evidence", Contemporary Economic Policy, vol. 16, No. 1, Fountain Valley, Western Economic Association International.

Solow, R. (1956), "A contribution to the theory of economic growth", Quarterly Journal of Economics, vol. 70, No. 1, Oxford, Oxford University Press.

Straub, S. (2008a), "Infrastructure and growth in developing countries: Recent advances and research challenges", Policy Research Working Paper, No. 4460, Washington, D.C., World Bank, January.

(2008b), "Infrastructure and development: A critical appraisal of the macro level literature", Policy Research Working Paper, No. 4590, Washington, D.C., World Bank, April.

Straub, S., C. Vellutini and M. Warlters (2008), "Infrastructure and economic growth in East Asia", Policy Research Working Paper, No. 4589, Washington, D.C., World Bank, April.

Urrunaga, R. (2010), "Relevancia de la infraestructura y análisis de los sobrecostos que genera su déficit", Apuntes, No. 65, Lima, Universidad del Pacifico, January.

Vásquez, A. and L. Bendezú (2008), Ensayos sobre el rol de la infraestructura vial en el crecimiento económico del Perú, Lima, Consorcio de Investigación Económica y Social (CIES)/ Central Reserve Bank of Peru. 